UDC 334.012.82:380.8:658.5

DOI: https://doi.org/10.32840/2522-4263/2021-1-27

Tsviliy Serhii

Candidate of Sciences (Economics), Associate Professor, Associate Professor of the Department of Tourism, Hotel and Restaurant Business National University "Zaporizhzhia Polytechnic"

Gurova Daria

Candidate of Sciences (Geography), Associate Professor, Associate Professor of the Department of Tourism, Hotel and Restaurant Business National University "Zaporizhzhia Polytechnic"

Zhuravlova Svitlana

Candidate of Sciences (Economics), Associate Professor of the Department of Tourism, Hotel and Restaurant Business National University "Zaporizhzhia Polytechnic"

Цвілий С.М. кандидат еконолічних наук, дочент, доцент кафедри туристичного, готельного та ресторанного бізнесу Національного університету «Запорізька політехніка»

Гурова Д.Д. кандидат географічних наук, дочент, доцент кафедри туристичного, готельного та ресторанного бізнесу Національного університету «Запорізька політехніка»

Журавльова C.M. кандидат еконолічних наук, доиент кафедри туристичного, готельного та ресторанного бізнесу Національного університету «Запорізька політехніка»

\title{
EXPERT COUNSELLING FOR HOTEL COMPANIES ON PROTECTION OF MICRO-BUSINESS INTERESTS IN CORONAVIRUS CONDITIONS
}

\section{ЕКСПЕТНЕ КОНСУЛЬТУВАННЯ ГОТЕЛЬНИХ КОМПАНІЙ ЩОДО ЗАХИСТУ IHTEPECIB МIКРОБIЗНЕСУ В УМОВАХ КОРОНАВРУСУ}

\begin{abstract}
ANNOTATION
The article is devoted to the search for ways to increase the level of economic security of domestic enterprises of the hotel micro-business in the context of the COVID-19 coronavirus based on the study of the theoretical experience of the organizational and legal aspects of the international system of tourist formalities. A mechanism for creating an information hub for consulting micro-business in the region is proposed. The theoretical experience of the medical aspects of the international system of tourist formalities is generalized. A list of trends in medical formalities in the context of the coronavirus global tourism space has been compiled. The mission, goals, prospects and technologies for the functioning of the information and consulting hub to support micro-companies in the hotel sector of the Zaporizhzhia region are proposed. The benefits from the creation of this structure are determined.
\end{abstract}

Key words: consulting, tourism, medical formalities, hospitality, micro-enterprises, hub, hotel business.

\section{АНОТАЦІЯ}

Стаття присвячена пошуку шляхів підвищення рівня економічної безпеки вітчизняних підприємств готельного мікробізнесу в умовах дії коронавірусу COVID-19 на основі вивчення теоретичного досвіду організаційно-правових аспектів міжнародної системи туристичних формальностей Запропоновано шляхи розробки механізму створення інформаційно-консультаційного хабу для допомоги мікробізнесу. Узагальнено теоретичний досвід медичних аспектів міжнародної системи туристичних формальностей. Досліджено сутність поняття «туристичні формальності», яке дозволило констатувати, що формальності впроваджуються з метою дотримання державних пріоритетів. Сформовано перелік тенденцій медичних формальностей за сучасних умов коронавірусного глобального туристичного простору. Встановлено, що в Україні значного негативного впливу COVID-19 зазнали підприємства мікробізнесу в туризмі, гостинності та готельній сфері. Сформульовано місію, цілі, пріоритети та технологію функціонування інформаційно-консультаційного хабу з підтримки мікрокомпаній готельної сфери Запорізької області. Доведено, що організація діяльності цього хабу необхідна, як для регіональних органів влади, так і для суб'єктів сфери гостинності та готельного бізнесу Запорізької області. В регіоні у якості пілотного проекту передбачається створення за сприяння торгово-промислової палати на базі провідного закладу вищої освіти регіону хабу, який буде вирішувати задачі підтримки туристичних та готельних мікропідприємств, нових підприємств у сфері гостинності та підприємців-початківців, головною ідеєю якого $є$ надання інформаційно-консультативної допомоги мікропідприємцям у створенні власного механізму протидії негативним наслідкам COVID-19 та забезпеченні базового рівня безпеки туристичного і готельного бізнесу. Обґрунтовано, що створення віртуальної структури істотно допоможе в подоланні галузевого і територіального роз'єднання мікросуб'єктів туристичного процесу і буде сприяти поступовому включенню інформаційно-консультаційних механізмів саморегуляції й адаптації мікробізнесу регіону до коронавірусного середовища.

Ключові слова: консультування, туризм, медичні формальності, сфрера гостинності, мікропідприємства, хаб, готельний бізнес. 


\section{АННОТАЦИЯ}

Статья посвящена поиску путей повышения уровня экономической безопасности отечественных предприятий гостиничного микробизнеса в условиях коронавируса COVID-19 на основе изучения теоретического опыта организационноправовых аспектов международной системы туристических формальностей. Предложен механизм создания информационного хаба для консультирования микробизнеса региона Обобщен теоретический опыт медицинских аспектов международной системы туристических формальностей. Сформирован перечень тенденций медицинских формальностей в условиях коронавирусного глобального туристического пространства. Предложены миссия, цели, перспективы и технологии функционирования информационно-консультационного хаба по поддержке микрокомпаний гостиничной сферы Запорожской области. Определены выгоды от создания данной структуры.

Ключевые слова: консультирование, туризм, медицинские формальности, сфера гостеприимства, микропредприятие, хаб, гостиничный бизнес.

Formulation of the problem. The study of organizational and legal aspects of tourist formalities became relevant during the period of feeding the borders of states. Of course, people have the right to free movement, but they must follow certain rules, which are the tourist formalities introduced by the competent authorities of individual countries. Each of the types of tourist formalities pursues related goals in the general sense, but they are achieved by applying a set of country-specific rules for crossing state borders, sometimes even local borders of certain regions within the country, terms of stay in different countries, import of items and many related formalities.

Today, despite the declared freedom of movement, international tourism will remain under strict state control for a long time, due to the existing differences in the levels of socio-economic development of countries and peoples, their different legal understandings of categories such as order, morality and legality. Significant differences today exist in the essence of ideas about the level of general civilization, culture, organizational, legal and medical norms of the procedure for preventing new global threats, reactions to COVID-19 and methods of restricting tourist flows. From this point of view, in the context of a global pandemic, quarantine and restrictions on foreigners visiting countries have been introduced in most countries of the world in order to prevent the spread of the coronavirus, which has certainly led to a crisis in tourism and hotel sphere. Such harsh measures have a very high socio-economic cost for different areas of service and limit the rights of consumers of tourism services [1, p. 50].

In Ukraine, COVID-19 has been significantly affected by micro-businesses in tourism and sphere of hospitality, as they are the main sellers of a comprehensive tourism product. Thus, the practice of their operation in 2020 confirms the large number of claims for violations of consumer rights and complaints from buyers of travel services about the invalidity of ordered products and cases of cancellation of travel plans due to restrictions because of the entry into force of threats and dangers of the coronavirus environment. Under these conditions, hotel micro-companies suffer unjustified losses and need to provide them with urgent information assistance, additional knowledge on the specifics of doing business with COVID-19, to obtain advice on updating medical tourist formalities. That is why the chosen problem area of scientific research is logical, timely and relevant.

Analysis of recent studies. Turning to the theoretical and methodological and conceptual approaches to the study of certain aspects of tourist formalities, we should mention the works of M. Boyko, M. Buromensky, A. Vojciechowski, M. Hnatovsky, O. Yevtushenko, T. Lutska, E. Makarenko, S. Melnychenko, T. Mizerna, V. Mytsyk, A. Nalyvayko, T. Pulina, N. Sviridova, T. Tkachenko and others $[2 ; 3 ; 4]$. Practical aspects of realization of tourist formalities in local tourist and hotel business structures in the conditions of COVID-19 pandemic are considered in researches of V. Zaitseva, Yu. Filei [5], A. Vindyuk, T. Kuklina, D. Stechenko, P. Shelepnytsky and others. However, in the presence of a significant number of scientific ideas of domestic and foreign scientists today there are almost no comprehensive studies on the formation of effective approaches, tools, mechanisms for sustainable development of domestic tourism and hotel microenterprises in the coronavirus economy of Ukraine in the context of consumer protection.

The purpose of the study is to develop recommendations for creating an information hub for advising hotel micro-business enterprises in the region in the context of the COVID-19 pandemic to improve the protection of consumer rights based on the generalization of theoretical experience of medical aspects of the international system of tourist formalities.

The main material. The study of the essence of the concept of "tourist formalities" of a state allowed us to state that, first of all, formalities are introduced to ensure national security, combat illegal migration, international terrorism, drug trafficking, prostitution, etc., as well as to ensure the safety of travelers and environmental protection. The most important thing is the protection of state borders from uncontrolled migration and the country from terrorism, which is one of the most pressing global problems of mankind. The rigidity of the establishment and compliance with formalities affects the formation of international tourist flows, while complicating the free movement of people. In theoretical terms, the order of entry of foreign tourists to a country and the associated degree of "hardness or softness" of tourist formalities is in a kind of balance with the interests of the state on its security, public order, and the rights and freedoms of citizens.

In the context of the coronavirus pandemic, health formalities come to the fore, which means 
procedures related to the verification of compliance with the established vaccination requirements by persons crossing the border. The World Health Organization (WHO) has developed Vaccination Certificate Requirements for travel abroad, which is a practical guide for tourism organizations and tourists. International health regulations have been in force since 1951, which show that quarantine diseases of international importance include: plague, smallpox, cholera, yellow fever, and since 2020 - COVID-19. Thus, to prevent the spread of these dangerous diseases, health authorities resort to special sanitary measures. International human rights law guarantees everyone the right to the highest level of health and obliges states to take measures to prevent harm to the health of the population and to provide medical care to those in need. International human rights standards also stipulate that restrictions on certain rights and freedoms are permissible in situations of serious threats to the health of the population and emergencies that endanger the life of the nation. Such restrictions must be scientifically justified and legally enforced. If their application is not arbitrary or discriminatory and is limited in time, and human dignity is respected, then such restrictions lead to the achievement of the goal. Tourists should receive reliable information about the disease and protection from it before traveling to certain countries, and it is usually submitted in the form of a reminder to citizens, certified by the signature of the tour operator and the seal of the travel agency.

It should be noted that before the coronavirus period, the strictest health rules of vaccination applied only to yellow fever. The yellow fever zone is in America: Brazil, Bolivia, Colombia, Venezuela, Peru, Ecuador; in Africa: Zambia, Kenya, Tanzania, Ghana, Guinea, Nigeria, Sudan. Going to these countries, the tourist had to get vaccinated no later than a month before departure, get an international certificate of vaccination and a doctor's opinion on the absence of contraindications for travel. Without this medical formality, the tourist must be removed from the flight on the basis of medical rules. The violating tourist can be placed in an isolator for the incubation period. In case of contraindications to vaccinations (eg, pregnancy, colds, allergies to egg yolk), travel to these countries is impossible. As the risk of contracting an infectious disease exists in almost the entire territory, the presence of an international certificate when entering these countries is mandatory.

Since the end of 2019 , the world has faced a new disease caused by the coronavirus COVID-19. Usually, such viruses do not pose a threat to humans, however, coronaviruses can mutate quickly and become dangerous. A new strain of coronavirus can cause severe pneumonia, and the course of the disease depends on the person's immunity. Most of the people who died from the COVID-19 virus had health problems, and a significant num- ber of elderly people with chronic diseases were among them.

The coronavirus pandemic and the attempt to prevent or at least mitigate another dangerous wave of infections have forced EU member states to significantly restrict entry into their territory. As of the beginning of 2021, this is usually allowed only to EU citizens or holders of residence permits in the European Union and the Schengen area. Citizens of most non-EU countries have limited medical formalities and must have good reasons to enter.

The listed tendencies of medical formalities in the conditions of coronavirus global tourist space, certainly, are not completely settled neither in the international legal field, nor from a position of proper protection of the rights of consumers concerning reception of safe tourist service. On the one hand, domestic tourists should receive reliable information about the disease and protection from it before traveling to certain countries, and it is usually submitted in the form of a reminder to citizens, certified by the signature of the tour operator and the seal of the travel agency. On the other hand, in the conditions of the COVID-19 pandemic, additional organizational, legal and economic burdens fall on the operators of the tourist services market, which are micro-enterprises. An adequate mechanism has not yet been found to address information and consultation issues regarding the correct interpretation of certain changes in medical formalities under the terms of COVID-19 and proper consumer protection [6, p. 4].

It is known that in developed countries, the consumer is the main business entity, focused on the production of tourist products and the level of quality of tourist services. Too often, in order to regulate medical formalities and coronavirus changes in the consumer protection situation, legislators increase the responsibility of companies for violating the rights of informing tourists about the conditions for obtaining a quality and safe service. However, strengthening sanctions and liability for violating the rules of providing and selling dangerous tourist services under COVID-19 is considered ineffective to change the situation, because sometimes the profits from violating consumer rights are much more important for sellers of tourist services than fines.

Today, the basic incentive to improve the situation in the field of protection of the rights and interests of buyers and consumers of tourist and hotel services should be healthy competition between sellers of services in the field of tourism, because the companies are interested in the quality of the service, in the best value for money, so that the consumer has the right to choose and give preference to their offers. Consumer rights must prevail over the rights of sellers and producers. At the same time, consumer awareness in Ukraine is low. Buyers of tourist services are aware of the articles of the law "On Consumer 
Protection", but most refuse to raise the level of consumer culture regarding medical formalities.

In the information space of the domestic society there is a shortage of content for studying the rights of consumers of hotel products in the conditions of COVID-19. An effective way out of this situation should be to raise a certain level of consumer awareness and obtain a "basic level of consumer education" (lessons in schools, special and program courses in higher education, the organization of courses for responsible consumers). Every conscious tourist-traveler should feel responsible and aware of his personal role in improving consumer culture and safety. That is, the main factor in reaching a new quality level of protection and protection of the rights and interests of consumers is the legal and consumer awareness of a person who knows his rights and ways to protect them.

Addressing the specifics of selling a hotel product to end consumers, it should be noted that informing tourists about medical formalities, their changes in the coronavirus business environment, new approaches in the tourism and hotel sector about medical features in consumer protection is entrusted to microenterprises. By this logic, it would be appropriate to state the fact that in accordance with Art. 2 of the of the Law "On Accounting and Financial Reporting in Ukraine" from 01.01.2018 applies a new classification of enterprises with a division into micro, small, medium and large. Thus, micro-enterprises have book value of assets up to 350 thousand euro; net income from sales of products (goods, works, services) up to 700 thousand euro; average number of employees up to 10 persons [7].

It is clear that even in the era of business digitalization, the focus of micro-enterprises on end users of tourism and hotel services will not be able to provide $100 \%$ contactless forms of communication on the vector "seller-buyer" in the next decade. For these reasons, the principle of regional distribution of micro-business enterprises is still important. The number of small and micro-businesses increased in 2019 compared to 2015, which confirms the right direction of development of the Zaporizhzhia region (Fig. 1). Of course, it is extremely difficult to distinguish by this distribution of micro-enterprises by type of economic activity those business structures that are relevant to the field of hotel sphere.

Based on the experience of developed countries, it is concluded that in Ukraine, institutions to support micro-enterprises in the field of tourism and hospitality in terms of COVID-19, regardless of their name and organizational and legal form, should perform the following functions: of domestic tourist enterprises of micro-business with European partners, conducting organizational and structural audit, transfer of information, innovation and service technologies from research institutions to micro-business companies, cooperation with local authorities in the field of dissemination of information in tourism, organization of training of entrepreneurs on protection of rights consumers, research of innovative tourist potential of the region, organization of information, consulting, financial, legal, educational services, cooperation with micro-business support organizations and experts in the field of tourism law, medical formalities, protection of consumer rights, vaccination of tourists, hospitality.

The term "hub" is becoming increasingly popular information and consulting structure, and its general essence is increasingly covering European countries, and Ukraine is no exception. Unfortunately, not all micro-business entities are familiar with hubs and not everyone understands the purpose. The information and consulting hub should be the result of a community of like-minded people whose interests are focused on making micro-business in tourism and hotel economically safe, legally protected, attractive and effective by providing modern, high quality and unique services to consumers. The practice of domestic formation of hubs testifies to their emergence on the basis of transformation, mainly of social phenomena (development of the city, district, community, etc.). From the standpoint of combining information and consulting interests in mastering medical formalities, modern knowledge on consumer protection and increasing the economic security of micro-business companies, such a virtual place should be the center of information and consulting initiatives, consultations, non-formal learning, workshops, birth area partnership projects to combat COVID-19.

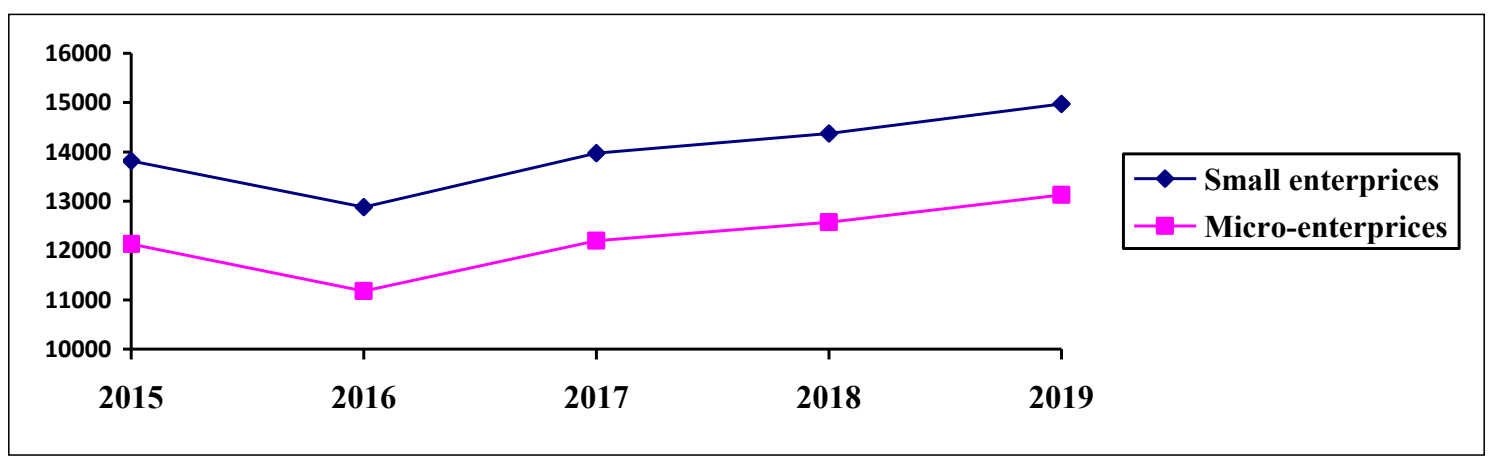

Fig. 1. Changing the number of small and micro-enterprises in the Zaporizhzhia region 
The authors of this study propose the creation of an information and consulting hub to increase awareness of medical formalities, economic security, protection of the interests of tourist and hotel enterprises of micro-business in the Zaporizhzhia region in terms of COVID-19. Understanding the mission and the basic need to create an information and consulting hub, first of all, must be mastered by micro-business entities. However, the general goal will be as follows: the hub should take place as a center of information and consulting activities, a digital educational space that integrates the interests of stakeholders in the hospitality industry of Zaporizhzhia region, who want to constantly develop, seek new ideas for survival, growth of their own economic safety and sustainable development in the context of coronavirus factors, seek not only theoretical knowledge but also practical skills to address issues of consumer protection in tourism and hospitality regarding the mastery of information on medical tourist formalities.

A promising and effective measure aimed at creating a coronavirus framework for the development of medical tourism formalities in the field of micro-business in modern conditions, can be an organization with the assistance of the Chamber of Commerce (CCI) information and consulting hub for micro-entrepreneurship in the region. The organization of this hub is necessary both for regional authorities and for the subjects of hospitality and hotel business of Zaporizhzhia region. The main task of the information and consulting hub is organizational, legal, regulatory and digital support in the field of consumer protection of businessmen who have long been operating in the field of hospitality and developing travel micro-firms. These micro-firms are beginning to interact with public or private entities on the basis of operational agreements that provide for their participation in regional and local tourism development. The wide scope of coverage makes it possible to provide various information and consulting services to strengthen the economic security of firms and to establish cooperation with specialized services. In the Zaporizhzhia region as a pilot project it is planned to create an information and consulting hub on the basis of the National University "Zaporizhzhia Polytechnic" (NU “ZP") with the assistance of the Chamber of Commerce and Industry (CCI), which will support travel micro-firms, new hospitality, startup entrepreneurs. The main idea of the hub is to provide information and consulting assistance to micro-entrepreneurs in creating their own mechanism to counter the negative effects of COVID-19 and ensure consumer protection.

The operational goals of the information and consulting hub are defined: creation of a virtual "section" (using Internet technologies) for public acquaintance of potential participants with world changes of medical formalities in tourism (1); providing comprehensive organizational and le- gal support and educational training, consulting and information services to start-up entrepreneurs and existing business entities in the Zaporizhzhia region in the field of medical formalities (2); development of entrepreneurial innovative thinking in students through the introduction of training programs for practical tools to work on changes in medical formalities (teamwork, collective legal decision-making, time management, discussion, development of creative initiatives to protect the rights and solve problems of consumers in tourism, information communicative perception of legal information, medical consultations, webinars with the participation of representatives of micro-business enterprises to share experiences of survival and economic security in the conditions of COVID-19 (3); involvement in active cooperation of legal and health departments of state local authorities in the context of updating and promoting the idea of micro-entrepreneurship in tourism and hotel sphere in the Zaporizhzhia region (4); discussion of practical issues of functioning of domestic hotel micro-business in the conditions of COVID-19 and the leading experience of obtaining knowledge of medical formalities in the EU between students and entrepreneurs (5).

The technology of functioning of the information-consulting hub of the National University "Zaporizhzhia Polytechnic" is presented in fig. 2.

The creation of such a structure will significantly help in overcoming the sectoral and territorial separation of micro-entities of the tourism process and will facilitate the gradual inclusion of information and consultation mechanisms for self-regulation and adaptation of hotel micro-business in the region to the coronavirus environment. It should be added that the combination of the principles of centralism inherent in the market economy, characteristic of the Ukrainian mentality, and equal partnership in the activities of the information and consulting hub will create the most favorable conditions for adapting Ukraine's hospitality to the crisis in tourism. In addition, the presence of such integration structures in the domestic regions will greatly facilitate the solution of organizational and financial issues related to the formation of regional data banks of medical formalities and networks of information support of tourism and hotel sphere, in particular public information management of tourism.

The functions of NU "Zaporizhzhia Polytechnic" include: motivation of micro-entrepreneurship in the formulation of problems, their selection and analysis (1); information support of micro-enterprises (2); creating conditions for a full-fledged creative process (3); involvement (advertising, information messages) of hub participants (4); creation and functioning of the Internet-resource (site) as a platform for a virtual hub (5); advisory assistance in matters of consumer protection, study of medical formalities, counteraction to COVID-19 (6). 


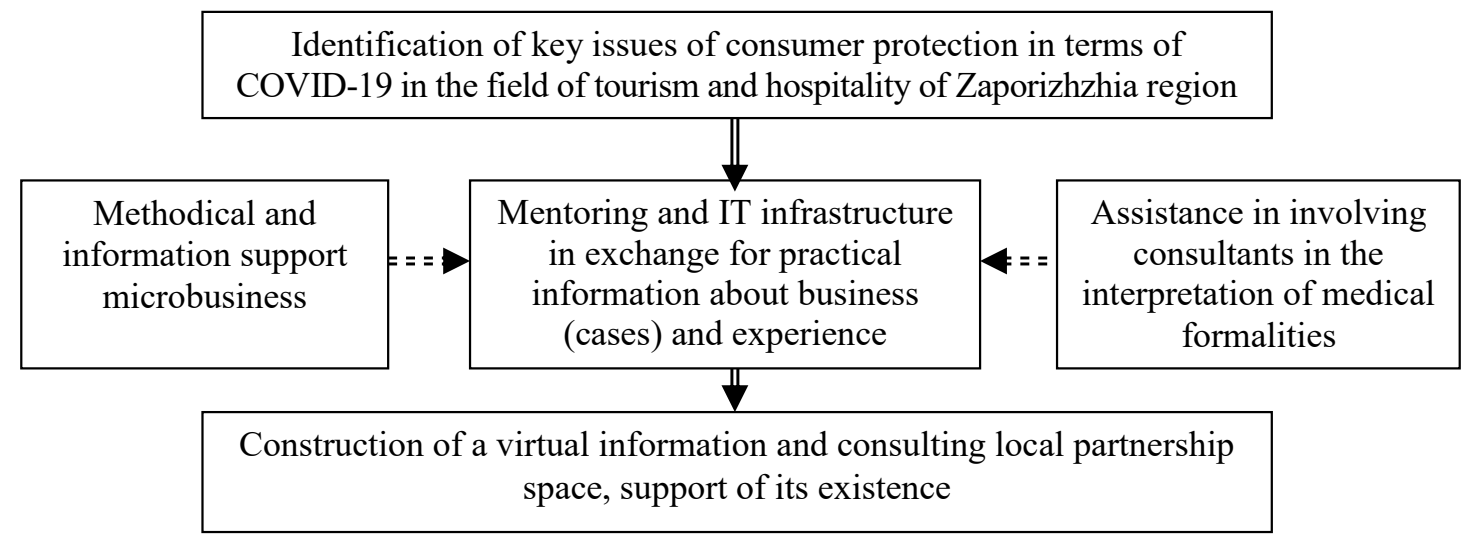

Fig. 2. Technology of functioning of information-consulting hub

The functions of the Chamber of Commerce and Industry include the promotion of the idea of supporting the micro-business of the region in the media space: during the exhibition activities of the chamber (1); link to the site of NU "ZP" with the presentation of the information and consulting hub (2); consultations on medical formalities (3); networking assistance to start-up entrepreneurs (4).

Information support of the hub operation and the basis for solving micro-business problems: informing about the goals of the information and consulting hub (1); information support of the hub operation (2); promotion of hub services (3); search and attraction of consultants, partners, donors, investors (4); public presentation of the results of the information and consulting hub (5); collecting suggestions and feedback on the operation of the hub, establishing and maintaining contacts with potential participants in the information and consulting hub (6).

Conclusions. Thus, the role of the state today is not only to generate a system of rules for the functioning of tourism market participants and monitor compliance through the formation of a favorable institutional environment and information and consulting infrastructure, but also to assist micro-companies in overcoming crisis factors in tourism and tourism hospitality. Government institutions should facilitate the provision of legal aid, additional knowledge on the regulation of the specifics of doing hotel business in the context of the COVID-19 pandemic and obtaining advice on the latest medical and tourist formalities. The basic activity of information and consulting hubs is to conduct an audit for hotel micro-enterprises in the region, which will systematize the medical and tourism needs of micro-enterprises. Prospects for further research should be the integration mechanisms within the country of information and consulting hubs, information and analytical agencies, research and consulting legal centers, higher education institutions, private entrepreneurs in tourism in national networks to support micro-enterprises in postcoronavirus strategy of their economic security.

\section{REFERENCES:}

1. Tsviliy, S. M., Vasylychev, D. V., Gurova, D. D. (2020) Improvement of the qualification of small and micro-enterprise staff in the crisis conditions of business transformation. Ekonomichnyy visnyk DVNZ "UDKHTU”. № 1 (11)/20. S. 50-60.

2. Voytsikhovs'kyi, A. V. (2020) Mizhnarodne pravo [International law]: pidruchnyk. Kharkiv. 544 s.(in Ukrainian)

3. Makarenko, Y. A. (2016) Mizhnarodna informatsiyna bezpeka: teoriya i praktyka [International information security: theory and practice]: pidruchnyk. Kyyiv : TVP. 417 s. (in Ukrainian)

4. Mytsyk, V. V. (Eds.) (2019) Mizhnarodne publichne pravo [International public law]: pidruchnyk. Kharkiv : Pravo. T. 2. $624 \mathrm{~s}$. (in Ukrainian)

5. Zaytseva, V. M., Filei, YU. V. (2010) Pravove rehulyuvannya turystychnoyi diyal'nosti [Legal regulation of tourism]: navchal'nyy posibnyk. Zaporizhzhya : Prosvita. $220 \mathrm{~s}$. (in Ukrainian)

6. Gurova, D. D. (2019) The modern economic impact of tourism. Pryazovs'kyy ekonomichnyy visnyk. Vyp. 6 (17). S. 3-7.

7. Zakon Ukrayiny "Pro bukhhalters'kyy oblik ta finansovu zvitnist' v Ukrayini" [Law of Ukraine "On Accounting and Financial Reporting in Ukraine"]. URL: https://zakon.rada.gov.ua/laws/ show/1023-12 (in Ukrainian) 